\title{
Financial Analysis of Broiler Production Units
}

\author{
Sudhakar Dwivedi ${ }^{1 *}$, Shubham Sharma ${ }^{1}$, Ashish Kumar Isher ${ }^{1}$, Pawan Kumar Sharma ${ }^{2}$ and P.K. Rai ${ }^{3}$ \\ ${ }^{1}$ Division of Agricultural Economics \& ABM, SKUAST-Jammu, JEK, INDIA \\ ${ }^{2}$ Directorate of Extension, SKUAST-Jammu, JEK, INDIA \\ ${ }^{3} A d v a n c e$ Centre for Horticulture Research ACHR, SKUAST-Jammu, JEK, INDIA \\ *Corresponding authors: S Dwivedi; E-mail: dwivedi.sudhakar@gmail.com
}

Received: 17 Aug., 2020

Revised: 12 Sept., 2020

Accepted: 20 Sept., 2020

\begin{abstract}
The present paper entitled "A Study of Income and Investment Pattern of Broiler Production Units" was carried out on the basis of primary data collected through pre-tested schedule-cum-questionnaire with personal interview method. For purpose of the study, three groups of broilers units were selected purposely and classified as per bird size. Group I included birds below 2000 in numbers, group II included birds 2001-5000 in numbers and group III included birds $5001 \&$ above in numbers. 15 broiler units were selected from each group, thus a total of 45 broiler units were studied. Kathua district of Jammu Kashmir Union Territory was selected purposively as the district has highest numbers of broiler production units. The cost of production includes variable cost and fixed cost, on first group broiler farms per lot cost of broiler production comes to ₹ 147112.45 for 1486.66 birds, on second group ₹ 367243.52 for 3666.66 birds and ₹ 959446.94 for 9466.66 birds respectively. The benefit-cost ratio per farm/ lot observed highest on third group farms i.e. 1:52 followed by 1:35 on second group, 1:17 on third group, while it is 1:44 on overall on sampled farms.
\end{abstract}

\section{HIGHLIGHTS}

(0 Financial analysis of broiler production units was done in Union Territory of Jammu Kashmir.

(0) The number of chicks in broiler units ranged between 2000 and 6000.

(0 The benefit-cost ratio per farm- per lot was 1:44.

Keywords: Broiler units, income, production, benefit-cost ratio

In India, poultry industry has made rapid progress in the last three decades not only in size but also in productivity, technology up gradation and quality as per strictest EU/ USA norms. India is the fifth largest producer of poultry meat in the world after USA, China, Brazil and Mexico (Anonymous, 2006). Poultry meat production increased from 81 thousand tonnes in 1961 to 1900 thousand tonnes in 2005 with an increase of 8.7 per cent and 6 per cent per annum during the eighties and nineties respectively (Mehta et al., 2003). Poultry production is unique in that it offers the highest turnover rate and the quickest returns to investment outlay in the livestock enterprises (Sanni and Ogundipe, 2005). Funds invested in poultry production are recovered faster than in any other livestock enterprise. The rate of growth in production of poultry is the highest when compared with ruminants and other monogastric animals (Braenkaert et al., 2002) and the cheapest, common and the best source of animal protein (Ojo, 2002).

Meat is the major component of poultry industry. Poultry meat (Boiler) is an important source of high quality proteins, minerals and vitamins to balance the human diet. Specially developed breeds of chicken meat (broiler) are now available with the ability of quick growth and high feed conversion efficiency. Depending on the farm size, broiler farming can be a main source of family income or

How to cite this article: Dwivedi, S., Sharma, S., Isher, A.K., Sharma, P.K. and Rai, P.K. (2020). Financial analysis of broiler production units. J. Anim. Res., 10(5): 821-825.

Source of Support: None; Conflict of Interest: None क्) 
can provide subsidiary income and gainful employment to farmers throughout the year. Poultry manure has high fertilizer value and can be used for increasing yield of all crops. Besides a good agricultural component for quick return, broilers act as a major source of poultry meat in the country. Broiler production in India was merely 4 million in 1971 which had increased to 1250 million in 2000, further to 1563 million during the year 2006 and further to 3160 million during 2012 (FAO). The profitability of production mostly depends upon good parent stock, quality chicks and feed (Islam et al., 2002), which has been made possible through a well-planned indigenization and acclimatization; with the result their productivity has been improved systematically to the levels at par with the developed countries.

The per capita per annum availability in India is about 42 eggs and $1.6 \mathrm{~kg}$ broiler meat while as the recommended per capita per annum consumption as per our nutritional board is 180 eggs and $9 \mathrm{~kg}$ meat (Gupta et al., 2006). Thus, we are far behind the developed countries where the per capita per annum consumption level is 300 eggs and $11 \mathrm{~kg}$ of poultry meat.

Table 1: Cost of Production of Broiler (₹/per farm/per lot)

\section{MATERIALS AND METHODS}

For purpose of the study, three groups of broilers units were selected purposely and classified as per bird size: Group I included birds below 2000 in numbers, group II included birds 2001-5000 in numbers and group III included birds $5001 \&$ above in numbers. 15 broiler units were selected from each group, thus a total of 45 broiler units were studied. Kathua district of Jammu Kashmir (UT) was selected purposively as the district has highest numbers of broiler production units.

The data has been collected through personnel interview method with the help of pre-tested schedule and questionnaire; while secondary data will be collect from different sources.

\section{RESULTS AND DISCUSSION}

\section{Cost of broiler production}

The Table 1 depicts per farms cost of production in broiler enterprise in different categories of broilers farms. After the establishment of infrastructure, the broiler chicks are

\begin{tabular}{|c|c|c|c|c|c|c|c|}
\hline Sl. No. & Particulars & $\begin{array}{l}\text { Group I } \\
(\text { Lot=1486.66) }\end{array}$ & $\begin{array}{l}\text { Per 100 } \\
\text { Chicks } \\
\end{array}$ & $\begin{array}{l}\text { Group II } \\
(\text { Lot = 3666.66) }\end{array}$ & $\begin{array}{l}\begin{array}{l}\text { Per 100 } \\
\text { chicks }\end{array} \\
\end{array}$ & $\begin{array}{l}\text { Group III } \\
(\text { Lot }=9466.66)\end{array}$ & $\begin{array}{l}\begin{array}{l}\text { Per 100 } \\
\text { chicks }\end{array} \\
\end{array}$ \\
\hline \multicolumn{8}{|c|}{ Variable cost } \\
\hline 1 & Chicks & 44599.80 & 3000.00 & 117333.12 & 3200.00 & 331333.10 & 3500.00 \\
\hline 2 & Total Feed & 51289.77 & 3450.00 & 122833.10 & 3350.00 & 307666.50 & 3250.00 \\
\hline 3 & Vaccination & 6541.30 & 440.00 & 16133.30 & 440.00 & 41653.30 & 440.00 \\
\hline 4 & Medicine & 9068.63 & 610.00 & 22366.63 & 610.00 & 57746.63 & 610.00 \\
\hline 5 & Total labour & 8176.63 & 550.00 & 20166.63 & 550.00 & 52066.63 & 550.00 \\
\hline 6 & Electricity & 3121.99 & 210.00 & 7699.99 & 210.00 & 19879.99 & 210.00 \\
\hline 7 & Veterinary fee & 6764.30 & 455.00 & 14666.65 & 400.00 & 33133.31 & 350.00 \\
\hline 8 & Miscellaneous & 2973.32 & 200.00 & 7333.33 & 200.00 & 18933.33 & 200.00 \\
\hline 9 & Water & 1486.66 & 100.00 & 3666.66 & 100.00 & 9466.66 & 100.00 \\
\hline 10 & Total & 134022.40 & 9015.00 & 332199.42 & 9060.00 & 871879.40 & 9210.00 \\
\hline 11 & Interest on variable cost @ 7.5\% & 10051.68 & 676.12 & 24914.95 & 679.50 & 65390.95 & 690.75 \\
\hline \multicolumn{2}{|c|}{ Total variable cost } & 144074.08 & 9691.12 & 357114.37 & 9739.50 & 937270.35 & 9900.75 \\
\hline \multicolumn{8}{|c|}{ Fixed cost } \\
\hline 1 & Rent for 35 days & 1263.00 & 84.95 & 5499.99 & 150.00 & 10602.65 & 112.00 \\
\hline 2 & Depreciation on fixed assets & 1486.66 & 100.16 & 3666.66 & 89.74 & 9466.66 & 73.98 \\
\hline 3 & Total Cost & 2749.66 & 185.11 & 9166.65 & 239.74 & 20069.31 & 185.98 \\
\hline 4 & Interest on fixed cost @10.50\% & 288.71 & 19.43 & 962.50 & 25.10 & 2107.28 & 19.52 \\
\hline \multicolumn{2}{|c|}{ Total fixed cost } & 3038.37 & 204.54 & 10129.15 & 264.84 & 22176.59 & 205.50 \\
\hline \multicolumn{2}{|c|}{ Total cost } & 147112.45 & 9825.66 & 367243.52 & 10004.34 & 959446.94 & 10106.05 \\
\hline
\end{tabular}


brought in batches/ lots. The cost of production includes variable cost and fixed cost. On first group broiler farms per lot cost of broiler production comes to ₹ 147112.45 for 1486.66 birds, on second group ₹ 367243.52 for 3666.66 birds and ₹ 959446.94 for 9466.66 birds respectively.

The cost of chicks contains the highest cost item in all categories of farms followed by cost of feed, interest on variable cost, cost of medicine, cost of labour, cost of vaccination, veterinary fee, miscellaneous, depreciation on fixed assets, interest on fixed capital and rent. The total cost of production of per 100 chicks comes to ₹ 9825.66 on group first, ₹ 10004.34 on second group farms and $₹ 10292.23$ on third group farms respectively. The cost of chicks and cost of feed are the major cost items in broiler production on all categories of farms. The cost of per 100 chicks on different broiler farm comes to $₹ 3000.00$ for first group, $₹ 3200$ for second group and ₹ 3500 on third group respectively, while the cost of feed varies to $₹ 3450$ on first group, $₹ 3350$ on second group and $₹ 3250$ on third group respectively. The cost of medicine is the next important item of cost which comes to ₹ 610 on all three groups of farms for 100 birds respectively. The broiler production is a labour intensive enterprise as it comes to ₹ 550 on all three group broiler farms under study. A close perusal of table depicts that the percentage share of variable cost to total cost comes to about 97 per cent on different group of farms, while the percentage share of fixed cost to total cost varies to 2.10 per cent to 3.10 per cent on different categories of poultry farms under study.

\section{Production and returns from broiler farms}

The Table 2 revealed the production of main-product, overall average number of birds produced were 4406.98, while as in case of group first, average number of birds were 1315.8 and the average weight per birds was $1.25 \mathrm{~kg}$.
In the case of group second the average number of birds produced was 3300 and the average weight of per bird was $1.37 \mathrm{~kg}$ while the average number of birds produced on group third was 8605.16 and the average weight was $1.34 \mathrm{~kg}$ per birds. Thus, there was not much variation in the average weight neither per birds nor in the quantity of meat produced per birds among the farm groups. The overall weight was $1.34 \mathrm{~kg}$ per farms and overall quantity was 59.93 quintal per farms, price per quintal ₹ 11266.66 per farms and average total value was ₹ 675210.93 per farm.

Table 2: Production status of sampled farm

\begin{tabular}{lllll}
\hline $\begin{array}{l}\text { Particular/ Farm } \\
\text { size }\end{array}$ & Group-I & Group-II & Group-III & Overall \\
\hline Main Product & & & & \\
\hline No. & 1315.8 & 3300 & 8605.16 & 4406.98 \\
Average wt.(kg) & 1.25 & 1.28 & 1.37 & 1.34 \\
Qt.(q) & 16.44 & 42.24 & 117.9 & 59.93 \\
Price/q (₹) & 10100 & 11500 & 12200 & 11266.66 \\
Value (₹) & 166044 & 485760 & 1438380 & 675210.93 \\
\hline By-Products & & & & \\
\hline Manure & & & & \\
\hline Qt.(q) & 26 & 43 & 81 & 50 \\
Price/q (₹) & 225 & 225 & 225 & 225 \\
Value (₹) & 5850 & 9900 & 18225 & 11325 \\
\hline Gunny Bags & & & & \\
\hline No. & 29 & 72 & 186 & 95.6 \\
Price/bag (₹) & 8 & 9 & 10 & 9 \\
Value (₹) & 232 & 648 & 1860 & 931.15 \\
\hline Gross Income & 172126 & 496308 & 1458465 & 687467.08 \\
\hline
\end{tabular}

The Table 3 depicts the group wise per farm/ per lot cost of broiler production, gross income, net income and benefitcost ratio. The overall per farm/per lot total cost comes to ₹ 491267.637 varies to ₹ 147112.45 on first group farms, ₹ 367243.52 on second group farms and ₹ 959446.94 on third group broiler farms under study. The per farm/

Table 3: Income from broiler production (main product) (₹ Per lot /Per farm)

\begin{tabular}{lllllll}
\hline Broiler farms & Variable cost & Fixed cost & Total Cost & $\begin{array}{l}\text { Gross Income/ } \\
\text { lot }\end{array}$ & Net Income/lot & C.B. Ratio \\
\hline Group I & 144074.08 & 3038.37 & 147112.45 & 172126.00 & 25013.55 & $1: 1.17$ \\
Group II & 357114.37 & 10129.15 & 367243.52 & 496308.00 & 129064.5 & $1: 1.35$ \\
Group III & 937270.35 & 22176.59 & 959446.94 & 1458465.00 & 499018.1 & $1: 1.52$ \\
\hline Overall & 479486.2667 & 11781.37 & 491267.637 & 708966.33 & 217698.7 & $1: 1.44$ \\
\hline
\end{tabular}


Dwivedi et al.

Table 4: Returns from broiler production (₹/100 chicks)

\begin{tabular}{|c|c|c|c|c|c|c|c|}
\hline \multirow{2}{*}{ Broiler farms } & \multirow{2}{*}{$\begin{array}{l}\text { Main Product } \\
\text { Value }\end{array}$} & \multirow{2}{*}{$\begin{array}{l}\text { By-product } \\
\text { Manure }\end{array}$} & \multirow{2}{*}{$\begin{array}{l}\text { Other Income } \\
\text { Gunny Bags }\end{array}$} & \multirow{2}{*}{ Gross Income } & \multirow{2}{*}{ Total Cost } & \multirow{2}{*}{ Net Income } & \multirow{2}{*}{ C.B. Ratio } \\
\hline & & & & & & & \\
\hline Group I & 12625.00 & 444.60 & 42.55 & 13112.15 & 9691.12 & 3421.03 & $1: 1.35$ \\
\hline Group II & 16100.00 & 443.18 & 45.00 & 16588.18 & 9739.50 & 6848.68 & $1: 1.70$ \\
\hline Group III & 16714.00 & 470.64 & 48.80 & 17233.44 & 9900.75 & 7332.69 & $1: 1.74$ \\
\hline Overall & 15146.33 & 452.81 & 136.35 & 15735.49 & 9777.12 & 5958.37 & $1: 1.61$ \\
\hline
\end{tabular}

lot gross income on overall farms comes to ₹ 708966.33, ₹ 172126 on first group farms, ₹ 496308 on second group farms and ₹ 1458465 on third group farms respectively. The per farm/lot net income on overall farms comes to ₹ 217698.7, while it was ₹ 25013.55 on first group farms, $₹ 129064.5$ on second group farms and ₹ 499018.1 on third group of broiler farms respectively. The benefit-cost ratio per farm/lot observed highest on third group farms i.e. 1:52 followed by 1:35 on second group, 1:17 on third group, while it was 1:44 on overall on sampled farms under study.

Table 4 further indicated that the return from the mainproduct and by-product from broiler production per hundred chicks. The gross income over all average was $₹ 15735.49$ while as in case of group I was ₹ 13112.15 , group II was ₹ 16588.18 and similarly group III was ₹ 17233.44 respectively. While as in case of net income over all average is $₹ 5958.37$, out of which in group I was ₹ 3421.03 , group II was ₹ 6848.68 and group III was ₹ 7332.69 respectively. Similarly whereas in case of cost benefit ratio overall average was 1.61 out of which in group I was 1.35, group II was 1.70 and group III was 1.74 respectively.

\section{CONCLUSION}

The cost of production includes variable cost and fixed cost, on first group broiler farms per lot cost of broiler production comes to ₹ 147112.45 for 1486.66 birds, on second group ₹ 367243.52 for 3666.66 birds and ₹ 959446.94 for 9466.66 birds respectively. The study further shows that the percentage share of variable cost to total cost comes to about 97 per cent on different group of farms, while the percentage share of fixed cost to total cost varies to 2.10 per cent to 3.10 per cent on different categories of poultry farms under study. The overall average number of birds produced was 4406.98 whereas the overall average price/quintal was ₹ 11266.66 . The benefit-cost ratio per farm/lot observed highest on third group farms i.e. 1:52 followed by $1: 35$ on second group, 1:17 on third group, while it is 1:44 on overall on sampled farms under study. In case of Returns from broiler production (₹ 100 chicks), the overall average cost benefit ratio was 1.61 .

\section{REFERENCES}

Acharya, K.P and Kaphle, K. 2015. Major issues for sustainable Poultry Sector in Nepal. Global J. Anim. Sci. Res., 3(1): $227-$ 239.

Anonymous, 2006. Executive guide to World Poultry Trends. Watt Publishing Company, Mt. Morris, Illinois.

Bandara, R.M.A.S. and Dassanayake, D.M.W.K. 2006. A quantitative analysison factors affecting profitability of small scale broiler production. J. Agri. Sci., 2(3): 93-98.

Bano, R. Shah, H. Sharif, M. and Akhtar, W. 2011. Profitability index and capital turn over in open house broiler farming: case study of district Rawalpindi Pakistan. J. Agri. Res., 24(4): 1-4.

Braenkaert, R.D.S., Gavirial, L., Jallade, J. and Seiders, R.W. 2000. Transfer of technology in poultry production for developing countries. Paper presented Worlds Poultry Congress, Montreal, Canada, 20-24.

Dwivedi, S., Sharma, P.K. and Sehar, H. 2010. Investment and income pattern in poultry production: A case study of Baramulla District of Jammu and Kashmir. Res. J. Agri. Sci., 1(3): 262-265.

Gupta, J.J., Doley, S. and Yadav, B.P.S. 2006. Study on rural poultry production in Meghalaya. Indian J. Poultry Sci. 41(1): 108-110.

Islam, F., Hossain, M.H., Akhtar, A and Hossain, M.S. 2014. Prospects and challenges in Broiler farming of Barguna District in Bangladesh. J. Bio-Sci. Agri. Res. 2(1): 44-51.

Islam, M.S. Howlinder, M.A.R., Kabir, F. and Alam, J. 2002. Comparative assessment of fertility and hatchability of Barred Plymouth Rock, White Leghorn, Rhode Island Red and White Rock Hen. Int. J. Poult. Sci., 1(4): 85-90. 
Naidu, N.G. 2002. Innovative marketing strategies for broiler integrators. Poultry Fort., 4(6): 13-15.

Ojo, S.O. 2002. Increasing household protein consumption through improved livestock production. Proc. Nigerian Soc. Anim. Prod., 27(4): 342-344.

Pradeshi, P.G., Kulkami, A.N., Mule, R.S., Poul, S.P., Baswade, S.V. 2011. Effect of sanitary measures on performance of broiler chickens in Marathwada region of Maharashtra, India. Vet. World, 4(8): 371-373.

Rajendran, K., Mohan, B., Vishwanathan, K and Edwin, S.C. 2008. A study on cost of production of Broiler at market age at Palladam area. Tamil Nadu J. Vet. Anim. Sci., 4(2): 69-70.

Rana, K.M.A.A., Rahman, M.S. and Sattar, M.N. 2012. Profitability of small scale broiler production in some selected areas. Prog. Agri., 23(1 \& 2): 101 -109.

Reddy, R.P., Shanmugam, T.R. and Mohan, B. 1997. Economic and financial analysis of broiler production in Kamarajar District of Tamil Nadu. Int. J. Anim. Sci., 12(1): 119-122.
Sammi, S.A. and Ogandipe, S.O. 2005. Economics of some modules of broiler production in Kaduna State, Nigeria. Nigerian J. Anim. Prod., 32(1): 102-107.

Sharma, R.K.D.S. 2003. A study on constraints encountered by broiler farmers in Haryana. Indian J. Poult. Sci., 38(3): 302304.

Singh, S. 1995. Marketing of poultry products broiler marketing, Indian J. Agri. Mark., 9(1): 51-61.

Singh, VP., Sharma, V.K., Sidhu, M.S. and Kingra, H.S. 2010. Broiler production in Punjab- an economic analysis. Agricultural Econ. Res. Rev., 23(1) 315-324.

Shailkh, A.S. and Zala, YC. 2011. Production performance and economic appraisal of broiler farms in Anand District of Gujarat. Agricultural Econ. Res. Rev., 24/2) 317-323.

Yadav, M.P. and Kumar, D. 2008. Poultry: Technically the most advanced sector. Hindu Survey Indian Agri., pp. 93-95. 
